\title{
Deterrence and Desert in Tort: A Comment
}

\author{
David G. Owen $\dagger$
}

I

Tort law has always been an incomplete social mechanism for dealing with injuries. For many centuries, it has provided remedies for limited forms of debiberately inflicted harm, such as assault, defamation, and deceit. ${ }^{1}$ The doctrine for such torts has becoine so wooden over time, however, that even the most objectionable, dehiberately inflicted harm sometimes ships through the cracks and escapes the system. ${ }^{2}$ Modern accident law began with the refinement of neghigence theory during the nineteenth century. ${ }^{3}$ Although accident law had earher freed itself of its restrictive limitation to redress for harm that was directly caused, ${ }^{4}$ negligence theory by definition excluded froin the systein the large category of accidents not caused by fault. And Rylands v. Fletcher ${ }^{5}$ and Greenman v. Yuba Power Products, Inc. ${ }^{6}$ notwithstanding, tort law has never been comfortable imposing true strict hability for accidents caused in the absence of provable fault. ${ }^{7}$ Tort law thus has developed as a system of

$\dagger$ Professor of Law, University of South Carolina. B.S. 1967, J.D. 1971, University of Pennsylvania.

Two of my colleagues, Dennis Nolan and Patrick Hubbard, and a visiting colleague from Oxford University, Christopher Whelan, reviewed and commented on an earher version of this Comment. Dr. Whelan's suggestions were very-helpful; Professor Nolan's were typically punctilious; Professor Hubbard's were characteristically quizzical. Van Hipp provided helpful research assistance.

1. See generally W. Keeton, D. Dobbs, R. Keeton, \& D. Owen, Prosser and Keeton ON THE LAW OF TORTS chs. 1, 2, 18, 19 (5th ed. 1984) [heremafter cited as Prosser \& KeETON].

2. See, e.g., Cucinotti v. Ortmann, 399 Pa. 26, 159 A.2d 216 (1960) (thugs who terrorized plaintiffs not hable for assault without also committing overt act).

3. Negligence doctrine was refined and expanded broadly during the latter half of the nineteenth century. See generally Gregory, Trespass to Negligence to Absolute Liability, 37 VA. L. REv. 359 (1951); Schwartz, Tort Law and the Economy in Nineteenth-Century America: A Reinterpretation, 90 YALE L.J. 1717 (1981). But cf. Rabin, The Historical Development of the Fault Principle: $A$ Reinterpretation, 15 GA. L. REV. 925 (1981).

4. See Gregory, supra note 3; Schwartz, supra note 3.

5. 3 L.R.- E. \& I. App. 330 (H.L. 1868), aff'g 1 L.R.-Ex. 265 (1866), rev'g 159 Eng. Rep. 737 (Ex. 1865).

6. $59 \mathrm{Cal} .2 \mathrm{~d}$ 57, 377 P.2d 897, 27 Cal. Rptr. 697 (1963).

7. A recent dramatic example is Feldman v. Lederle Laboratories, 97 N.J. 429,479 A.2d 374 (1984), in which the New Jersey Suprene Court effectively overruled Beshada v. Johns-Manville 
principles for redressing certain types of harm ${ }^{8}$ caused by certain types of behavior $^{9}$ by certain types of injurers ${ }^{10}$ to certain types of victims ${ }^{11}$-a "systein" incomplete at best.

Tort law traditionally has been described as "private" law, concerned with private wrongs, ${ }^{12}$ meaning a wrong is determined only upon the victim's inotion, and is rectified for his personal benefit from resources belonging to the injurer. Yet the private law model has not fit tort law well, as courts and commentators increasingly have applied a functional perspective. Tort law can be viewed as having two broad functions: coinpensation and punishınent. The compensation function ${ }^{13}$ focuses on the victim's losses arising out of the damaging event and serves to satisfy the victin's needs. The punishment function ${ }^{14}$ focuses on the quality of the injurer's damaging conduct, and examines in particular whether the conduct sliould be stigmatized and discouraged by declarmg it unlawful and by compelling the injurer to rectify the victim's loss. While in the abstract one inight view the pursuit of these functions narrowly as a private matter of corrective justice between the parties, both the need to coinpensate the victim and the need to punish the injurer typically involve considerations far beyond the interests of the parties, broadly affecting the interests of many others. ${ }^{15}$ Thus, while tort

Products Corp., 90 N.J. 191, 447 A.2d 539 (1982), which had imposed a true strict liability standard on manufacturers to warn of unknowable dangers in their products.

8. There may be, for example, no liability for economic loss. See, e.g., Sacramento Regional Transit Dist. v. Grumman Flxible, 158 Cal. App. 3d 289, 204 Cal. Rptr. 736 (1984).

9. There may be, for example, no hability for wrongful prosecution of a civil suit. See generally Prosser \& KEETON, supra note $1, \S 120$.

10. There may be, for example, no liability on the part of governmental entities. See, e.g. Thompson v. County of Alameda, 27 Cal. 3d 741, 614 P.2d 728, 167 Cal. Rptr. 70 (1980) (county immune under statute governing discretionary acts such as parole or prisoner release).

11. There may be, for example, no liability for harm to persons who "assume" a risk. See generally Prosser \& KEETON, supra note $1, \S 68$.

12. See, e.g., T. Cooley, A TReatise on the LAW of Torts 6-7, $81-90$ (1880); W. Hale, Handbook on the Law of Torts 5-8 (1896); Stoll, Penal Purposes in the Law of Tort, 18 AM. J. COMP. L. 3 (1970).

13. I use the word "function" cautiously, but I think it best describes the true role of compensation in the law of torts. Although compensation in a sense is the ultimate objective of most liability rules and judgments in tort law, it cannot strictly speaking be called a tort law "goal" or "rationale." This is because compensation is appropriate only when liability is appropriate. Liability is appropriate only if the injurer's act was "wrong," and only certain acts are wrong for certain reasons. It is these reasons in social policy and justice for declaring acts wrongful (tortious) that are the true "goals," "purposes," and "rationales" of tort law, not compensation. Compensation is simply the deserving victim's remedy once the injurer is found appropriately responsible according to the goals of tort. See Owen, Rethinking the Policies of Strict Products Liability, 33 VAND. L. REv. 681, 703-07 (1980) (characterizing compensation as a "one-directional objective" of social policy).

14. Punishment, too, is better described as a tort law "function," rather than as a "goal." Strictly speaking, punishment only describes the detriment inflicted upon an injurer who, for certain reasons, has been found deserving of the detriment.

15. The victim's compensatory needs, for example, as well as the interests of various third parties, are affected by whether the victim carries first party insurance. Moreover, for the many 
law functions in a common law judicial system that is concerned with the determination and rectification of private wrongs, it is often public in its spirit and effect. ${ }^{16}$

Professor Stephen Sugarman's masterful article, Doing Away with Tort Law, ${ }^{17}$ lucidly and comprehensively catalogues the many failures of the present common law tort system to deal fairly or effectively with either compensation or pumishment. His call to separate the two functions, to expand compensation to disadvantaged persons generally, ${ }^{18}$ and to bury tort law in the process, is a bold proposal that goes beyond most other law reform plans. Most of Professor Sugarman's criticism of the tort system in operation is well-founded, in my opinion, as is much of his critique of existing tort theory and of the more modest reforms proposed by others. ${ }^{19}$ Of special interest are his observations on the problems with the deterrence and desert objectives of the present law, and his views on their proper role in a society devoid of an accident law of torts.

\section{II}

Compensation and punishment in the law of torts are both centrally concerned with the distibution of appropriate deterrents and deserts among the victim, the injurer, potential victims, and potential injurers. So stated, the notion of "desert" broadly includes both a "positive" side (compensating the victim) and a "negative" side (punishing the injurer). Professor Sugarman's critique and proposal comprehensively examines both aspects of the desert issue. My purpose here is to highlight some fairness problems with certain aspects of negative desert and deterrence concepts as justifications im the law of torts. ${ }^{20}$

policies underlying the law of crimes, society generally has substantial interests in the determination of whether punishinent should be inflicted upon injurers.

16. See generally J. Fleming, The LAw of TorTS ch. 1 (6th ed. 1983); Prosser \& KeEton, supra note $1, \S \S 2-4$.

17. 73 Calif. L. Rev. 555 (1985).

18. Although Professor Sugarman persuasively argues for a functional view of the compensation problen, which would logically include illness and congenital disability within the system, he fails (perhaps appropriately) to go the final step. There are in fact many other persons in need of compensation. They include those with classifiable mental disease, and the many persons who suffer froin a large variety of inental conditions-including laziness and plain stupidity-who by consequence receive less incoune from the system than they need. Carrying the functional approach to its conclusion therefore leads to a more radical, social-welfare solution to the compensation problen. Specifically, it would appear to mandate a system of national health insurance and a governmentally guaranteed ininimun wage, as by a "negative income tax."

19. Among the general plans for accidental harm, see, e.g., Franklin, Replacing the Negligence Lottery: Compensation and Selective Reimbursement, 53 VA. L. REv. 774 (1967); Pierce, Encouraging Safety: The Limits of Tort Law and Government Regulation, 33 VAND. L. REv. 1281 (1980).

20. Many of the fairness issues discussed here have been explored by others, including Professor Sugarman in his current article, and I acknowledge the comununity of scholarship on many of these points. The tort law fairness issues I discuss bear repeating or amplification, however, in a comment on an article proposing that tort law be abolished. 
"Retribution" and "corrective justice" are both, in major respects, negative desert ideas. Behind both concepts is a belief in the existence and importance of free will. Persons are therefore properly held account$a^{2} e^{21}$ for their choices to advance their own interests at the expense of the interests of others. Unless one subscribes to a theory of strict liability, ${ }^{22}$ choices of action producmg harm are measured against some standard of propriety. Both concepts postulate that if a victim's injuries are caused by a breach im the standard of propriety-if, that is, the injurer's choices were "wrongful" according to the standard-the injurer may fairly be required to recompense the victim for his loss. This serves the purposes of providing psychological "satisfaction" to the victim-who receives pleasure from causing the injurer himself now to suffer-and of restorimg to society a proper balance in the social order. ${ }^{23}$

Both retribution and corrective justice are in principle fair objectives for the law of torts and caimot be dismissed as lightly as Professor Sugarman would do. Yet both in apphication may cause major unfair hardship on defendants. A recurring fairness problem in this respect goes to the lack of any necessary equivalence between the degree of harm (and the victim's corresponding "positive" desert) and the degree of wrong (and the mjurer's corresponding "negative" desert). Even the shightest deviation from the legal standard will result in liability under the present system and most tort models. ${ }^{24}$ There is therefore no necessary correlation between the degree of moral failure of the injurer in exercising his will in a certain way and the needs of the victim who has suffered loss. It is hardly fair from the injurer's perspective to require him to pay the victim more in compensation than is reflective of the mjurer's wrong and of his economic station. ${ }^{25}$ The penalty, in common

21. That is, persons can properly be required to explain their choices to sacrifice the interests of others for personal gain. This requirement of explanation by no means implies that liability should attach to such decisions, however, since they may be perfectly proper on both fairness and efficiency grounds.

22. As does Professor Richard Epstein, for example, in Epstein, A Theory of Strict Liability, 2 J. LEGAL STUD. 151 (1973).

23. These principles are more thoroughly explored in Owen, Punitive Damages in Products Liability Litigation, 74 MiCH. L. REv. 1257, 1279-82 (1976).

24. Professor Clarence Morris, in a superb little essay, was one of the first to discuss this problem in Morris, Rough Justice and Some Utopian Ideas, 24 ILI. L. REv. 730 (1930). See also Fleming, The Role of Negligence in Modern Tort Law, 53 VA. L. REv. 815, 817-18 (1967). For a discussion of the economic implications of this plienomenon, see Cooter, Unity in Tort, Contract, and Property: The Model of Precaution, 73 CALIF. L. Rev. 1 (1985); see also Cooter, Prices and Sanctions, 84 CoLUM. L. REV 1523 (1984).

25. Although conventional doctrine precludes consideration of the injurer's wealth on either the underlying liability issue or on the amount of compensatory damages, it is in principle relevant at least to the latter issue. The adage that it takes a greater penalty to punish a rich man than a poor one is well known in the context of punitive damages (and in criminal law) in this country. See generally Morris, Punitive Damages in Tort Cases, 44 HaRv. L. REv. 1173 (1931); Owen, supra note 23, at 1318. In certain otlier countries, such as Switzerland, Turkey, Argentina, and most of the 
penal parlance, should fit the wrong-yet only sometimes does the amount of harm reflect the degree of wrong. The scales of justice are hardly righted by requiring a slightly guilty injurer to relieve the victim of his entire loss; they are only tipped the other way. The imbalance is "corrected" from the victim's viewpoint only.

Besides its effort to "rectify" certain losses already suffered by the victim and society, tort law also in theory seeks to prevent such losses in the future. This deterrence function ${ }^{26}$ of the law of torts may be classified in different ways, including the directness of the effect of a tort law rule on potential injurers. A rule would provide what might be called "direct deterrence" if potential injurers conform their behavior to the rule specifically for the purpose of avoiding liability for its breach. This is the form of deterrence commonly used by courts to justify the creation or application of tort law rules. ${ }^{27}$ Alternatively, a rule may discourage conduct indirectly, through the conduct of third parties, as in the case of "market deterrence." This theory of deterrence posits that firms forced to absorb the costs of accidents arising from their goods or services may pass on these costs to consumers in the form of higher prices. As prices rise, the demand for the injurer's product or service may then decline, and the level of objectionable activity should thus decrease. ${ }^{28}$

Professor Sugarman describes many of the failures of deterrence theory to operate effectively im the world. ${ }^{29} \mathrm{My}$ concern here is that his focus upon the practical difficulties in achieving deterrence may divert attention from some problems of primciple that lurk within tort law's deterrence function. Direct deterrence in particular must be subjected to careful scrutiny for moral legitimacy since it is based upon the idea that one set of persons (injurers) should be harmed (forced to pay damages to current victims) for the purpose of benefiting a possibly unrelated set of persons (potential victims). If there is some other justification for forcing injurers to pay current victims-such as a valid theory of corrective justice that offers sufficient definitions and correlation of wrong, causation and penalty - then the protection of potential victims may be a morally acceptable, supplemental reason for harming injurers. Yet the naked

socialist nations, the defendant's wealth may be considered on the issue of compensatory damages. See Stoll, supra note 12, at 4, 18.

26. Like compensation and punishment, deterrence is best described as a "function" rather than as a "goal." See supra notes 13-14; Owen, Policies, supra note 13, at 709-10.

27. See, e.g., Taylor v. Superior Court, 24 Cal. 3d 890, 598 P.2d 854, 157 Cal. Rptr. 693 (1979) (punitive damages assessable for drunken driving); Rowland v. Christian, 69 Cal. 2d 108, 443 P.2d 561, 70 Cal. Rptr. 97 (1968) (creating ordinary duty of reasonable care for landowners and land occupiers instead of varying duty scheme based on entrant's classification as invitee, licensee, or trespasser).

28. See generally G. Calabresi, The Costs of Accidents (1970).

29. Others have also demonstrated various weaknesses in these theories. See, e.g., id.; Pierce, supra note 19. 
notion of deterrence does not itself provide such a moral justification, not even from a utilitarian perspective, but simply describes a process whereby harm is inflicted upon one type of person to benefit another.

Although market deterrence has some fairness problems in its operation, it is fair in its basic theory: persons who benefit from a good or service generally should pay for all the necessary costs of making the good or providing the service. Problems arise due to imperfections in the market system and to changes in the legal rules. For example, if goods or services provided long ago result in liability only now, it is unlikely that firms at the earlier time correctly computed the costs of accidents and internalized those costs in prices paid by consumers at that time. ${ }^{30}$ Instead, many firms probably increase current prices to include at least soine of the present costs of accidents caused by earlier "underpriced" goods and services. To the extent that current goods and services otherwise differ from the earlier ones, and to the extent that the firm's customers have changed over time, current consumers are unfairly being made to subsidize the earlier consumers.

Professor Sugarman's article describes many inadequacies in the objectives of deterrence and desert as proper functions in tort law. The fairness problems in these aspects of tort theory lend support to Professor Sugarman's basic proposition that the law of accident compensation is in serious need of substantial reform.

\section{III}

If our accident law of torts should be abolished, as one day it probably should, a question arises whether there is any remaining place in the legal systein for retribution or deterrence. I think there is.

For one thing, although Professor Sugarman waffles on the point, ${ }^{31}$ I believe that some form of punitive damages should be retained for intentional torts. ${ }^{32}$ The goals of retribution, corrective justice, and deterrence are inost appropriate in redressing intentionally inflicted harm.

30. It is now a matter of historical fact that at least the insurance industry failed to anticipate how fast and far medical malpractice and products liability would spread in the 1970's. The rate of exposure to liability seems to be expanding substantially even now. See, e.g., Malcolm, Doctors Prepare Attack on Suits for Malpractice, N.Y. Times, Feb. 15, 1985, at A1, col. 2 (noting release of final AMA task force report on malpractice hability and insurance).

31. Sugarman, supra note 17 , at $659-60$.

32. In New Zealand, the one nation which has abolished the accident law of torts, at least one court has held that exemplary (punitive) damages are not barred by the New Zealand Accident Compensation Act. See Donselaar v. Donselaar, [1982] 1 N.Z.L.R. 97 (N.Z. Ct. App.). Professor Love, whose comprehensive study of punitive damages under no-fault legislation focuses especially on the U.S. workers' compensation statutes, also advocates the retention of punitive damages as a means to punish and deter intentional wrongdoers. See Love, Punishment and Deterrence: A Comparative Study of Tort Liability for Punitive Damages Under No-Fault Compensation Legislation, 16 U.C.D. L. REV. 231 (1983). 
This is because intentional torts often represent a kind of "theft"33 which is plainly wrong, which if possible should be discouraged in advance, and for which a just desert often will far exceed mere recoinpense of the stolen goods. ${ }^{34}$ Indeed, compensatory rehef should reinain available in the tort systein to intentional tort victims for all damages not covered by the compensation system, ${ }^{35}$ including pain and suffering and mental anguish. In addition, it seems only fair (and apparently efficient) to require the "thief" to pay the victim's loss-recovery costs through the payment of the plaintiff's litigation expenses, especially attorneys' fees. ${ }^{36}$

If punitive damages are to be allowed, there are a variety of difficult problems that need to be addressed. Perhaps most important is to assure that only injurers who truly deserve to be pumished are subjected to punitive assessments. Not every instance of an intentional tort should support a punitive award, for some intentional torts involve true moral reprehensibility and extreme departures from acceptable behavior, ${ }^{37}$ while others do not. Batteries in almost every case would demonstrate behavior that is flagrantly improper, requiring ${ }^{38}$ a pumitive award, while many instances of misrepresentation passing technically as deceit would not. ${ }^{39}$ The injurer's wrongful state of mimd would have to be defined precisely to minimize the risk of inflicting punishment not deserved. ${ }^{40}$

Various procedural safeguards would also be required to prevent punitive damages froin being assessed unfairly and inefficiently. ${ }^{41}$ As a starting point, a "clear and convincing evidence" standard of proof

33. See Owen, Civil Punishment and the Public Good, 56 S. CAL. L. REv. 103, 109-12 (1982).

34. A victim's just desert in this context will exceed compensatory damages because such damages fail to cover litigation costs or to assuage the mental anguish from having been victimized deliberately by a thief. See Owen, Punitive Damages, supra note 23, at 1295-99. An intentional injurer needs to be punished in excess of compensatory damages to take the profit out of injuring and to adjust for the tendency of injurers to discount the liketihood of being caught and punished. See id. at 1282-95.

35. And perhaps, since the tort was intentionally committed, the reasons supporting the collateral source rule would support recovery of the damages covered by the compensation system as well. See generally D. DoBBS, HANDBOOK ON THE LAW OF REMEDIES $\$ 8.10$ (1973).

36. See, e.g., Owen, Forward: The Use and Control of Punitive Damages, 11 WM. MrTCHELI L. REv. 309, 314-15 (1985); Owen, Punitive Damages, supra note 23, at 1297-99.

37. The "extreme departure" standard is explained in Owen, supra note 33, at 115-16.

38. I use "require" rather than "permit" because I behieve that a truly culpable, intentional injurer is a kind of thief who should in faimess be forced to pay all of the victim's damages includimg the administrative costs of recovering his "stolen goods." Punitive damages, at least in part, serve this purpose. See supra notes 33-36 and accompanying text.

39. Tort claims for misrepresentation classically lay only in deceit, an intentional tort, as the House of Lords held in the famous case of Derry v. Peek, 14 App. Cas. 337 (1889). Many jurisdictions still purport to follow the rule, but stretch the notion of "intent" far down the culpability scale well into the area of mere negligence. See generally Prosser \& KEeTON, supra note $1, \S 107$.

40. See Ellis, Fairness and Efficiency in the Law of Punitive Damages, 56 S. CAL. L. REv. 1, 3353 (1982).

41. See generally Wheeler, The Constitutional Case for Reforming Punitive Damages Procedures, 69 VA. L. REV. 269 (1983). 
should be adopted. ${ }^{42}$ In addition, the risk of excessive awards should be reduced by establishing certain limits. Punitive assessments could be limited to some multiple of the victim's actual damages, say treble damages; to some percentage of the imjurer's financial posture, say ten percent of imcome or net worth; to some absolute maximum amount, say $\$ 100,000$; or to some combimation of the above. ${ }^{43}$ Witl safeguards such as these, deterrence and desert should always play an important role in redressing intentional torts.

In accident law, at least deterrence should continue to play a role. With tort law bamished in this area, the deterrence function will have to be shifted, as Professor Sugarman points out, from judgments for compensatory damages in the courts to penalties imposed by regulatory agencies. In particular, the regulatory agencies should be required to collect and analyze accident data, to disseminate safety information to the public, to help establisli safety standards, to monitor compliance, and to punish violations of reporting requirements ${ }^{44}$ and safety norms. As presently is the case, pumishment could be effected through civil fines and, when necessary, through action banning the hazardous product or activity altogether-as by requiring a manufacturer to recall its products ${ }^{45}$ or an

42. See id. at $296-98$.

43. For example, legislation in Connecticut currently limits punitive damages in products liability cases to twice the amount of coinpensatory damages awarded to the plaintif. See CONN. GEN. STAT. ANN. § 52-240b (West Supp. 1983). A new statute in Montana limits punitive damages in most tort cases to the greater of $\$ 25,000$ or one percent of the defendant's net worth. See Montana Puts Cap on Punitive Damage Awards, Nat'l L.J., April 22, 1985, at 7, col. 1. In addition, a minimum amount or floor for such awards should be prescribed, to be certain that the plaintiff recoups his costs of litigation, as discussed above. See supra note 36 and accompanying text; see also Owen, supra note 23 , at 1315.

44. It would be imperative to purish rigorously any reporting violations in a regime depending on the regulatory sector to perform meaningful deterrence. There are recent indications that stiffening such penalties may currently be a high priority at the safety regulatory agencies. For example, the Environmental Protection Agency (EPA) recently fined Union Carbide $\$ 3.9$ unillion for withholding new findings on possible health risks from the chennical diethyl sulfate. Wall St. J., March 4, 1985, at 10, col. 2. In another recent example, Honeywell, Inc. paid the Consumer Products Safety Commission (CPSC) $\$ 800,000$ in civil penalties for failing to report hazards in some of its gas controls for furnaces, space heaters, and water heaters. Loss PREvENTION AND CoNTRol (BNA), Feb. 19, 1985, at 3, col. 2 .

In addition, a victim who could establish a causal connection between his injuries and the injurer's violation of a reporting rule might be given the right to recover something in the nature of a civil fine, plus attomeys' fees. Cf. Wilson ex rel. Lincoln National Bank \& Trust Co. v. Robertshaw Controls Co., 600 F. Supp. 671 (N.D. Ind. 1985) (finding private right of action existed for violations of CPSC reporting rule). I would limit standing for the recovery of such fines or "bounties" to persons actually imjured by such violations, rather than endorse Professor Sugarman's unlimited squeal-for-profit plan. See Sugarman, supra note 17, at 654-55.

45. Automotive recalls are now a very common phenomenon, and drugs and durable consumer products are also subject to occasioual recall. For example, the Consumer Product Safety Commission has recently decided to investigate the dangers in three-wheel, all-terrain vehicles (ATV's), and one commissioner believes that the agency should give "serious consideration" to halting their production and requiring a recall. Emergency room reports on ATV accidents indicated the following 
airline to ground its planes. ${ }^{46}$ Finally, one must not underestimate the power of an agency to affect the market for a product or a service through publicizing safety hazards. ${ }^{47}$ The federal safety agencies generally have these powers now, so that hittle tinkering would be necessary to the existing federal regulatory scheme to put a progressive punishment package promptly in its proper place.

\section{IV}

An analysis of the compensation and funding portions of the Sugarinan proposal generally is beyond the scope of this essay, yet I should register concern on certain funding aspects of the scheine. Professor Sugarman's plan is very broad in its coverage and exceedingly generous in its benefits. I sense that he has no real idea of the enormity of the funding requirements necessary to finance such an extraordmary undertaking in American society. For example, he seeins to assume quite casually that the very generous sick-leave benefit prograins now provided by "progressive" einployers can simply be required of all employers. This proposal in particular nay pose some serious problems.

For one thing, rather than being progressive in a social consciousness sense, it may well be that such hiberal coinpanies are run unusually efficiently, and so have "extra" resources to spend on einployee benefits. Some such companies may be in a monopolistic position not enjoyed by nuany others. Possibly the liberal benefits may reflect the presence of a powerful labor union. The point is that sick-leave benefits are a significant aspect of eniployee coinpensation which, in Sugarmanian dimensions, represents a very substantial cost to the enployer. This increase in cost would serve as an extra "tax" on all non-"progressive" employers. Many firıns would have substantial difficulty absorbing or passing on this extra cost of operation. Firms, and perhaps whole industries, that pres-

casualty rates: $1982-14$ deaths, 8,585 injuries; $1983-42$ deaths, 27,554 injuries; $1984-48$ deaths, 66,956 injuries (based on incomplete 1984 data). The State, Columbia, S.C., Apr. 4, 1985, at 7-A, col. 1; see also 13 Prod. SAfETY \& LiAB. ReP. (BNA) No. 14, at 221 (April 5, 1985).

46. Although airline groundings are a rare occurrence, the largest commuter airline in the country, Provincetown-Boston Airline, was grounded for safety violations by the Federal Aviation Adıninistration in 1984. See N.Y. Times, Nov. 11, 1984, at 1, col. 5.

47. See, eg., 12 Prod. SAFETY \& LiAB. REP. (BNA) No. 1, at 5 (Jan. 6, 1984) (CPSC's warning of the fire hazard posed by one brand of Christmas tree lights which could overheat and melt under certain conditions); 11 Prod. SAfETY \& LiAB. REP. (BNA) No. 28, at 525 (July 15, 1983) (CPSC's warnings to consumers of the strangulation hazard posed by expandable enclosures for small children). A recent issue of Consumer Reports, in its section on product recalls, noted the following product-safety alert concerning the latter hazard: "Accordian-style baby gate. V-shaped top edges and diamond-shaped openings in gate may trap toddler's head, possibly causing strangulation." Consumer REP., May 1985, at 268. Noting that some 10-15 million of such gates have been sold and that the CPSC has halted production of the product but is permitting inventories to be sold, the magazine recominends that consumers discard the gates and replace them with gates of a safer, non-accordian design. Id. 
ently operate on the margin of profitability would be forced out of business (or have to be subsidized) because of this extra tax. More fundamentally, it is difficult to see any strong connection between employment and the nature of the benefits-off-the-job accident and illness compensation - funded by the tax. This calls into question both the logic and fairness of the tax. Moreover, an employer-funded benefit plan of this type is by nature a regressive tax on workers, since most employers would probably mclude it at least to some extent on a pro rata basis in the computation of the total compensation package for employees. To the extent that the extra cost could be passed along in the form of higher prices, it would simply amount to a regressive sales tax on consumers. Regressiveness in the funding mechanism may be appropriate, yet that is an important political issue that needs careful examination.

Nor am I very comfortable with Professor Sugarman's rather daring suggestion that social cost accounting be ignored. Instead, I think that imstitutions should contribute to the compensation fund in amounts reflecting the risks inherent in their industry, and that individuals should contribute for engaging in selected high risk activities. This would diminish the free-rider problem in a broad-brush way. Fines and activity bans could be imposed on both institutions and persons to individualize cost allocations even further. Thus, at a general level, inotorcycle manufacturers or inotorcycle drivers (through their license fees) or both could be taxed especially steeply. Thereafter, fines and bans (through forcing recalls and revoking licenses) ${ }^{48}$ could be used to particularize punishment for manufacturers of defective motorcycles and reckless motorcycle drivers - both of whom otherwise would be free riders for causing more to be taken from the system than they contribute. The fairness and efficiency questions on the funding issue are numerous and exceedingly complex, and they need much further thought before any broad-based compensation plan can be given really serious consideration. ${ }^{49}$

\section{V}

Any fair critique of the traditional tort system's capacity to compensate and prevent accidental losses must recognize that it is a system limited in both respects by its theoretical basis in corrective justice. It is neither fair to injurers nor sensible economically for society to try to make more of the system than what it is. As Professor Sugarman ably demonstrates, the tasks of establishing fair and efficient systems for compensation and for accident deterrence are fundamentally separate tasks,

48. See supra notes $45-46$ and accompanying text.

49. See, e.g., Oi, Tort Law as a Regulatory Regime: A Comment on Landes and Posner, $13 \mathrm{~J}$. LEGAL STUD. 435 (1984) (emphasizing the need for a comparative cost analysis of tort law and regulation to determine the preferred approach for catastrophic injuries). 
and they far exceed in purpose and scope the narrow boundaries of tort law theory. Courts which try to force such tasks upon the law of torts have asked more of the system than it can take. ${ }^{50}$

One day, the legislatures should probably abolish the accident law of torts. The present tort law function of compensation necessarily will be transferred to some public welfare system. The pumishment function, particularly the deterrence of undue hazards, will shift to the public regulatory sector. It may to some seem naive, alas, to place responsibility in the regulatory sector for achieving the latter task, and Professor Sugarman's saccharine substitution of the administrative for the judicial process may show nore fancy than cominon sense. But the many fairness problems with deterrence and desert in tort law theory, and the many operational problems in the present tort law system, require that alternative proposals be accorded due consideration.

Yet the day of such major social welfare changes in our system is, I think, a long way off. This nation will have to become much wealthier, and the electorate will have to become much more oriented toward the values of egahtarianism and social welfare, before the legislatures think seriously about restructuring accident law entirely outside the tort law systein. Before that day arrives, however, there is much restructuring that can be done within the present systen to improve the law of torts. I agree that the more modest and conventional tort reform proposalssuch as changes in the rules on collateral sources, pain and suffermg, and punitive daniages-should continue to be pursued. But it seenss to me that more hope lies in exploring more fundaniental reforms. For example, serious consideration should be given to shifting to the English system on attorueys' fee awards. ${ }^{51}$ Further, I think there is considerable merit in a system that would provide accident victims with the option of pursuing either full tort damages on proof of negligence or prompt payment of economic loss alone on proof of causation. ${ }^{52}$ Changes such as

50. The California Supreme Court has arguably pushed tort law past its ability to solve social problems in a variety of contexts. See, e.g., Sindell v. Abbott Laboratories, 26 Cal. 3d 588, 607 P.2d 924, 163 Cal. Rptr. 132, cert. denied sub nom. E. R. Squibb \& Sons, Inc. v. Sindell, 449 U.S. 912 (1980) (imposing on unanufacturers of defective generic drug hability proportional to market share where identification of specific manufacturer not ascertainable); Taylor v. Superior Court, $24 \mathrm{Cal}$. 3d 890, 598 P.2d 854, 157 Cal. Rptr. 693 (1979) (assessing punitive damages for drunk driving); Tarasoff v. Regents of University of California, 17 Cal. 3d 425, 551 P.2d 334, 131 Cal. Rptr. 14 (1976) (imposing duty of care on therapist toward person specifically threatened by therapist's patient during treatment).

51. See generally D. DoBBS, supra note 35, at 194-200; Attorney Fee Shifting, 47 LAw \& CoNTEMP. PROBS. 1 (1984).

52. Senator Dodd of Connecticut recently has made an intriguing proposal in the products liability area. He would give the injured consumer an option to pursue a speedy no-fault claim against the manufacturer for economic losses, or a traditional judicial negligence action for full tort damages. See 131 CoNG. REc. S3183 (daily ed. March 19, 1985) (statement of Senator Dodd). This is very different from the elective no-fault proposal of Professor O'Connell, who would give the 
these might go a long way to improve the fairness problems with desert and deterrence in the law of torts.

The present tort system is far too costly and in many ways is most unfair. I join in the call for a renewed and vigorous debate on reforming the law of torts. 